diaries of 60,000 francs for studies abroad in the universities of Paris, London and Cambridge and at the College of France. Subsidiaries to scientific works amounted to 743,000 franes, and to scientific periodicals $2 \cdot 4$ million francs, while scientific associations received grants amounting to 903,000 francs and another 30,000 francs went to university associations. Progress is reported with the Index of Scientific Publications, of which two volumes are to appear in 1965, and the report includes a first list of periodicals which it is proposed to microfilm, as well as notes on relations with other institutions. Under the heading "Belgian American Educational Foundation" is given a list of bursars nominated in 1964-65.

\section{Euratom Information}

Euratom Information, issued by the Centre for Information and Documentation, Euratom, Brussels, is printed in German, French, Italian, Dutch and English. No. 3, Volume 3, March 1965, lists scientific and technical publications issued in connexion with the Euratom/ United States Joint Research and Development Programme, or the Joint Nuclear Research Centre, including reports of the European Atomic Energy Community. Lists of patents and of research contracts are provided, and each section has indexes of authors, inventors, firms and organizations.

\section{Scientific Research in British Universities and Colleges}

THE latest edition of Scientific Research in British Universities and Colleges for the year 1964-65 has been published by H.M.S.O. on behalf of the Department of Education and Science and the British Council (Vol. 1: Physical Sciences. Pp. xix +368 . 37s. 6d. net. Vol. 2: Life Sciences. Pp. xviii +404. 40s. net. London: H.M.S.O., 1965). This invaluable publication outlines scientific research in progress in British universities, colleges of advanced technology, national colleges, regional technical colleges in England and Wales, and equivalent colleges in Scotland and Northern Ireland. So far as possible, all research undertaken within faculties of science, medicine, engineering, technology and agriculture is included, as well as work of a scientific nature occurring within other faculties. This year's publication differs somewhat from previous years' editions. Because of an increasing amount of material, the publication has been arranged in two volumes and the arrangement is now according to subject. Volume 1 contains the physical sciences, both pure and applied, and Volume 2 the life sciences, including medicine and agriculture. Certain inter-disciplinary subjects (biochemistry, etc.) are included in both volumes. Each volume is divided into broad subject fields and within each field the material is arranged by university/college departments. As in previous editions, each entry includes the head of department and the names of permanent staff actually engaged in supervising research. The material for the universities was collected by the British Council and for the colleges by the Department of Education and Science. While the new style of the publication offers many advantages, it would have been a considerable help if the page numbers had been dropped to the base of the page and if the page headings had been brought to the outer margins; this arrangement would have made reference from the indexes considerably easier.

\section{Sir William Jackson Hooker}

Among botanists throughout the world, the name of Sir William Jackson Hooker is remembered for his inspired directorship of the Royal Botanical Gardens at Kew, and for passing on the good work to an equally eminent son when he died on August 12, 1865. Hooker senior was educated at Norwich School, and being of independent means was able to devote a lifetime to science. $\mathrm{He}_{\mathrm{e}}$ travelled extensively in Europe in his research work, and later travel brought him perpetuation in Mount Hooker in the Rocky Mountains as well as in the order of mosses, Hookeriales. On returning from an expedition to Iceland the ship in which Hooker was travelling caught fire and much of his collected material was lost. However, his memory was so keen that he was still able to publish a review of the work which he had carried out. He set up at Holesworth, Suffolk, a herbarium which rapidly gained international renown. Later he gave the herbarium, together with his fine library, to Kew. Although it was his son, Sir Joseph Dalton Hooker, who graduated M.D. at Glasgow, Hooker senior became linked with that University through his election to the chair of botany in 1820 at the age of thirty-five. In 1841 came his appointment as director of Kew, and it was there that Hooker's genius showed itself to the full. Through him the great collections of algae, lichens, ferns and other plants were greatly enriched. Apart from published works such as his two-volume Musci Exotici dealing with foreign mosses, and his editing of the Flora Londinensis of William Curtis-works greatly enhanced by Hooker's abilities as artist and illustrator-he found time to edit many journals, including the Botanical Magazine and the London Journal of Botany. His son kept up the good traditions of the Hooker family both through his expeditions and published work, and is remembered, among other things, for his encouragement of a raw youth named Charles Darwin.

\section{Perfumes against Pests}

Pests of the same family as carrot fly feed on the blossom of Umbelliferae and may be controlled by spraying the headlands. This observation suggested the possibility of using scents to attract and trap insects as an alternative to pesticides, and the Henry Doubleday Research Association undertook a pioneer experiment to test the idea (Perfumes Against Pests. Pp. 51. Bocking, Braintree, Essex: Henry Doubleday Research Association, 20 Convent Lane, 1965. 3s. 6d.). A range of twelve of the cheaper oils, seven from the order Umbelliferae and the remainder from plants used extensively for flavouring, were diluted with isopropyl alcohol and added to 10 per cent solutions of brown sugar. The solutions were placed in jars covered with a $3 / 16$-in. square hole mesh, to exclude bees and wasps, and the traps were usually sited at a sheltered position a short distance from the crop so as to attract the adult pests before egg laying. For fruit pests, the traps were hung in trees or set between bushes. The catches were analysed and tabulated and some preference trends indicated that coriander oil was best for cabbage root fly, onion fly and celery fly and had a broader spectrum than sweet fennel oil. Promising results were also obtained with parsley seed, dill, cumin seed and carraway oils, and from an apple blossom synthetic scent, and there were suggestions that both Barbados and Demerara sugars were attractants. The Association is prepared to supply outfits for further study.

\section{Rutherford Memorial Lecture and Scholarships}

UNDER the terms of the scheme to commemorate Lord Rutherford of Nelson, the Council of the Royal Society has made the following appointments. Rutherford Memorial Lecturer, Prof. P. I. Dee, professor of natural philosophy in the University of Glasgow, to be Rutherford Memorial Lecturer for 1965 in Canada, and to deliver the Lecture in Saskatoon on September 29, 1965. Rutherford Scholarships, Mr. S. D. Bradshaw, of the University of Western Australia, Perth, to a Rutherford Scholarship for three years, to work for the first year at the University of Sheffield (with arrangements for the subsequent years to be made later) on comparative studies on the factors controlling the secretion of adrenal hormones in mammals and reptiles with particular reference to the 